CENTRE for ECONOMIC

$\begin{array}{llllllllllll}P & E & R & F & O & M & A & N & C & E\end{array}$

CEP Discussion Paper No 1350

May 2015

\title{
Ill Communication: Technology, Distraction \& Student Performance
}

Louis-Philippe Beland Richard Murphy 


\begin{abstract}
This paper investigates the impact of schools banning mobile phones on student test scores. By surveying schools in four English cities regarding their mobile phone policies and combining it with administrative data, we find that student performance in high stakes exams significantly increases post ban. We use a difference in differences (DID) strategy, exploiting variations in schools' autonomous decisions to ban these devices, conditioning on a range of student characteristics and prior achievement. Our results indicate that these increases in performance are driven by the lowestachieving students. This suggests that restricting mobile phone use can be a low-cost policy to reduce educational inequalities.
\end{abstract}

Keywords: Mobile phones, technology, student performance, productivity JEL codes: I21; I28; O33; J24

This paper was produced as part of the Centre's Education and Skills Programme. The Centre for Economic Performance is financed by the Economic and Social Research Council.

We would like to thank Andriana Bellou, Vincent Boucher, Dave Card, David Karp, Briggs Depew, Christian Dustman, Ozkan Eren, Baris Kaymak, Stephen Machin, Naci Mocan, Ismael Yacoub Mourifie, Daniel Parent, Shqiponja Telhaj, Felix Weinhardt, and seminar participants at AEFP, APPAM, RES, IAWEE, University of Montreal and the University of Texas at Austin for comments and discussions. We would also like to thank Guillaume Cote, Fan Duan and Vlad Khripunov for excellent research assistance. Any remaining errors are our own.

Louis-Philippe Beland, Louisiana State University. Richard Murphy, University of Texas at Austin and Associate at Centre for Economic Performance, London School of Economics.

Published by

Centre for Economic Performance

London School of Economics and Political Science

Houghton Street

London WC2A 2AE

All rights reserved. No part of this publication may be reproduced, stored in a retrieval system or transmitted in any form or by any means without the prior permission in writing of the publisher nor be issued to the public or circulated in any form other than that in which it is published.

Requests for permission to reproduce any article or part of the Working Paper should be sent to the editor at the above address.

(c) L-P Beland and R. Murphy, submitted 2015. 


\section{Introduction}

Technological advancements are commonly viewed as leading to increased productivity. Numerous studies document the benefits of technology on productivity in the workplace and on human capital accumulation. ${ }^{1}$ There are, however, potential drawbacks to new technologies, as they may provide distractions and reduce productivity. Mobile phones can be a source of great disruption in workplaces and classrooms, as they provide individuals with access to texting, games, social media and the Internet. Given these features, mobile phones have the potential to reduce the attention students pay to classes and can therefore be detrimental to learning.

There are debates in many countries as to how schools should address the issue of mobile phones. Some advocate for a complete ban while others promote the use of mobile phones as a teaching tool in classrooms. This debate has most recently been seen with the Mayor of New York removing a ten year ban of phones on school premises in March 2015, stating that abolition has the potential to reduce inequality (Sandoval et al, 2015). ${ }^{2}$ Despite the extensive use of mobile phones by students and the heated debate over how to treat them, the impact of mobile phones on high school student performance has not yet been academically studied.

In this paper, we estimate the effect of schools banning mobile phones on student test scores. The lack of consensus regarding the impact of mobile phones means that there is no UK government policy about their use in schools. This has resulted in schools having complete autonomy of their mobile phone policy, and have differed in their approaches. We exploit these differences through a difference in differences (DID) estimation strategy. We compare the gains in test scores across and within schools before and after mobile phone bans are introduced.

In order to do this, we generated a unique dataset on the history of mobile phone and other school policies from a survey of high schools in four English cities (Birmingham, London, Leicester and Manchester), carried out in spring of 2013. This is combined with administrative data on the complete student population from the National Pupil Database (NPD). From this, we know the academic performance of all students since 2001, and so use differences in implementation dates of mobile phone bans to measure their impact on student performance.

\footnotetext{
${ }^{1}$ E.g: Kruger, 1993; Chakraborty and Kazarosian, 1999; Aral et al., 2007; Ding et al., 2009; and Malamud and PopEleches, 2011.

${ }^{2}$ Other examples of the debate are: Telegraph 2012; Childs, 2013; Barkham and Moss, 2012; Drury, 2012; O’Toole, 2011; Johnson, 2012; and Carroll, 2013.
} 
Moreover, the NPD tracks students over time, which allows us to account for prior test scores along with a set of pupil characteristics including gender, race, ever eligible for free school meals (FSM), and special educational needs (SEN) status. Although we do not know which individuals owned mobile phones, it is reported that over $90 \%$ of teenagers owned a mobile phone during this period in England; therefore, any ban is likely to affect the vast majority of students (Ofcom 2006, 2011). ${ }^{3}$ Even if a student does not own a phone themselves their presence in the classroom may cause distraction.

We find that following a ban on phone use, student test scores improve by $6.41 \%$ of a standard deviation. Our results indicate that there are no significant gains in student performance if a ban is not widely complied with. Furthermore, this effect is driven by the most disadvantaged and underachieving pupils. Students in the lowest quartile of prior achievement gain $14.23 \%$ of a standard deviation, whilst, students in the top quartile are neither positively nor negatively affected by a phone ban. The results suggest that low-achieving students are more likely to be distracted by the presence of mobile phones, while high achievers can focus in the classroom regardless of the mobile phone policy. This also implies that any negative externalities from phone use do not impact on the high achieving students. Schools could significantly reduce the education achievement gap by prohibiting mobile phone use in schools, and so by allowing phones in schools, New York may unintentionally increase the inequalities of outcomes. We include several robustness checks such as an event study, placebo bans, test for changes in student intake and range of alternative outcome measures.

The rest of the paper is organized as follows: Section 2 discusses the related literature; Section 3 provides a description of the data, survey and descriptive statistics; Section 4 presents the empirical strategy; Section 5 is devoted to the main results and heterogeneity of the impacts; Section 6 provides a series of robustness checks; and Section 7 concludes with policy implications.

\section{Related literature}

There is a growing literature on the impact of technology on student outcomes, which has yet to reach a consensus. Fairlie \& Robinson (2013) conduct a large field experiment in the US

\footnotetext{
${ }^{3}$ We further discuss phone ownership rates in Section 3. The focus of this paper is the impact of a school level policy which may have impact on students who own a phone, but also on students who don't own a phone but could still be distracted through the actions of others.
} 
that randomly provides free home computers to students. Although computer ownership and use increase substantially, they find no effects on any educational outcomes. Similar findings have occurred in recent randomized control trials (RCTs) in developing countries where computers have been introduced into the school environment (Barrera-Osorio and Linden, 2009; Cristia et al., 2012).

Some studies have found a positive impact from technology, such as Machin et al. (2006), who estimate the impact of information and communication technology (ICT) investment on student outcomes in England, using changes in funding rules as an exogenous shock to investment. They find that ICT investment has a positive effect on student test scores in English and science, but not for mathematics (where computers were rarely used). Barrow et al. (2009) examine the impact of structured computer aided instruction using a RCT design in three large urban school districts. They find that this math software had large impacts on students algebra test scores $(0.17$ of a standard deviation).

Specifically relating to mobile phones, Bergman (2012), as part of an RCT, used mobile phones to inform parents of students' homework assignments through texting. The students of parents who were sent messages achieved higher test scores. Fryer (2014) provided free mobile phones to students in Oklahoma City Public Schools in a field experiment. Students received daily information on the link between human capital and future outcomes via text. There were no measureable changes in attendance, behavioural incidents, or test scores. ${ }^{4}$ The common theme in these education papers is that the mere introduction of technology has a negligible impact on student test scores, but when incorporated into the curriculum and being put to a well-defined use, technology has the potential to improve student outcomes.

The psychological literature has also found that multitasking is detrimental to learning and task execution in experimental contexts. Recent experimental papers present evidence that mobile phone use while executing another task decreases learning and task completion (e.g. Ophir et al. (2009); Smith et al. (2011); Levine et al. (2013); and Lee et al. (2014)). The distracting nature of mobile phones has been previously examined in other context such as incidence of road accidents. Bhargava and Pathania (2013) exploit a pricing discontinuity in call plans and show that there is a

\footnotetext{
${ }^{4}$ However, Fryer (2014) does find that students' reported beliefs about the relationship between education and outcomes were influenced by treatment, and treated students also report being more focused and working harder in school.
} 
large jump in phone use after 9 p.m. This jump, however, is not followed by an increase in car accidents. Using vehicular fatality data from across the United States and standard difference-indifferences techniques, Abouk \& Adams (2013) find that texting bans have only a temporary impact on car accident fatalities, suggesting that drivers react to the announcement of a legislation only to return to old habits shortly afterward.

Our contribution is to estimate the effect of mobile phone bans on high stakes student test scores at the end of compulsory schooling, within schools that implemented them. This is of particular importance given the prevalence of mobile phone technology in schools today. Our data allows us to investigate which students are most strongly affected by mobile bans.

\section{Student Data, Phone Use and Survey}

\subsection{Student characteristics and performance}

The NPD is a rich education dataset of the complete public school population of England. ${ }^{5}$ It contains information on student performance and schools attended, plus a range of student characteristics such as gender, age, ethnicity, FSM eligibility and SEN status. Each student is allocated an individual identifier, which allows for the student to be tracked over time and across schools. We generate a dataset that follows students from the end of primary school at age 11 through the end of compulsory school education at age 16.

In England, students progress through a series of five Key Stages. Our paper focuses on secondary school students and their performance at the end of compulsory education examinations, as such they are high stakes exams and will have long run impacts on labor market outcomes. Students start secondary school at age 11 after completing Key Stage 2 in primary school. Key Stage 3 covers the first three years of secondary school and Key Stage 4 leads to subject-specific exams at age 16, called General Certificates of Secondary Education (GCSEs). The panel nature of the data allows us to condition on student achievement before they entered high school. Moreover, it allows us to test whether the introduction of the ban changed the composition of the school intake in terms of test scores or other student characteristics.

\footnotetext{
${ }^{5}$ Students attending private schools are not present in the data, but only represent $7 \%$ of the student population.
} 
Our main measure of student achievement is based on GCSE test scores from 2001 to 2011. Each GCSE is graded from $A^{*}$ to $\mathrm{G}$, with an $\mathrm{A}^{*}$ being worth 58 points and decreasing in increments of six down to 16 for a G grade. Students take GCSEs in different subjects; the mean number of GCSEs (or equivalents) taken in the sample is 9. We use an individual's sum of these GCSE points, standardized nationally each year, so that it has mean of 0 and standard deviation of 1. ${ }^{6}$ This is for ease of interpretation and to account for any grade inflation that may have occurred during this time period. ${ }^{7}$

We use alternative measures of student performance to examine the robustness of the results. First, we use a point score, which reflects the differences in the difficulty of attaining certain grades and student performance at Key Stage 3 (at age 14). Finally we use another standard measure of achievement that is widely recognized by the government and employers, which is whether a student earned a C or higher in at least five GCSEs, including English and math.

\subsection{Mobile phone survey}

There is no official policy or recommendation set out by the Department of Education in England regarding mobile phone usage in schools. Therefore, schools' mobile phone policies are decided at the school level by the headteacher and the school's governing body, which has resulted in a large variation in mobile phone policies. As information relating to school policies is not collected centrally, in the spring of 2013 we conducted a survey of high schools in four large cities in England (Birmingham, Leicester, London and Manchester) regarding their mobile phone policies. Before approaching schools, we obtained permission from the relevant Local Authorities. ${ }^{8}$ Every secondary school from Local Authorities where permission was granted was then contacted. This consisted of two personalized emails, and a follow-up phone call seven days after the second email, had we not yet received a reply. We invited the headteacher or school administrator to complete an online survey, or reply to the questions via email or over the phone. ${ }^{9}$

\footnotetext{
${ }^{6}$ In appendix Table A.6, we additionally provide results according to students' performance on their top eight subjects. ${ }^{7}$ Grade inflation would not affect the final results, as the inclusion of year effects would account for them. However, standardising by year does make the summary statistics easier to interpret.

${ }^{8}$ We did not obtain permission from five Local Authorities in London (Hackney, Lewisham, Newham, Redbridge and Tower Hamlets), which combined have 77 secondary schools. The City of London Authority does not contain any public schools and therefore was not approached. The remaining 27 London Local Authorities gave permission, with 337 secondary schools being approached.

${ }^{9}$ The survey questionnaire is presented in the Appendix. Survey website: http://mobilephoneatschool.weebly.com.
} 
The survey contained questions about the school's current policy toward mobile phones, when it was implemented, whether there was a previous mobile phone policy and, if so, when it was implemented. This was repeated until we could construct a complete mobile phone policy history at the school since 2000 . These questions were supplemented with questions relating to punishments for violating the policy and the headteacher's views on how well the policy was complied with. We also asked if there were any other policy or leadership changes occurring over the same time period, to account for any other changes in educational policy at the school. ${ }^{10}$

We received completed surveys from 91 schools, which represents $21 \%$ of the target high schools in the four cities in our sample. This response rate is comparable to other nongovernmental survey in academic research such as Card et al (2012), Hall \& Krueger (2012), Heffetz (2011) or Brau \& Fawcett (2006). Table 1 uses the NPD to illustrate the representativeness of the schools in our sample compared to schools in the cities and to England as a whole, over the entire period. Comparing standardized age 16 test scores, we see that schools in these cities score approximately the same as the national average, but that the schools in our sample over the whole period achieve significantly higher scores than other schools within these cities $(0.07 \sigma)$. In contrast, the cities have slightly lower age 11 achievement than the national average, and the sampled schools have an even lower intake quality $(-0.09 \sigma)$, although not statically significant at the 10\% level. Taken together, this implies that the schools in our sample over the 2001-2011 period have a higher gain in test scores than the average school. Despite this, the sample schools have a significantly more disadvantaged population than other schools in the cities and nationally, enrolling more minority, SEN and FSM -eligible pupils. There is no difference in the proportion of male students nationally, between the schools in surveyed cities or in the sample.

Table 2 presents statistics on when mobile phone policies were put into effect and how well they were complied with. There are a multitude of ways in which schools have restricted phone use, from asking for them to be set on silent to not allowing them on school premises. We define a school as introducing a school ban if that school did not allow them on the premises or required them to be handed in at the start of the day. Only one school in our sample did not restrict

\footnotetext{
${ }^{10}$ This is open to recall bias, but we would expect that headteachers would be very familiar with school-level policies and leadership changes. This is complemented by additional information on policy and leadership changes from each of the schools' websites. Examples of changes are: uniform policy, new buildings, girls allowed in schools and school mergers.
} 
the use of mobile phones between 2001 and 2011. Headteachers were asked to rate to what extent the policy was adhered to by students on a seven-point scale (with 1 meaning "not at all" to 7 meaning "completely"). A school was considered to have a high-compliance ban if the response was greater than four. The table shows that most bans were implemented between 2005 and 2010 , and that bans are typically complied with.

Table 3 provides descriptive statistics for the same characteristics of the surveyed schools pre- and post-ban introduction in comparison to other schools in their cities. The pre-policy averages allow us to compare the representativeness of the surveyed schools before the policies were introduced. We see that the responding schools look very similar to other schools in their cities in terms of their age 16 test scores, SEN, FSM and gender make up. The only considerable difference is that they tend to recruit lower achieving students and have more minority students.

Examining the post-ban characteristics provides the first evidence of any impact the policies may have along with any potential confounding changes in the compositions of the cohorts due to the change in phone policies. Comparing the changes over time, we see that student achievement at age 16 significantly increases post-policy compared to pre-policy, but that there is no corresponding significant improvement in the prior performance of the intake students to these schools. This implies that there is minimal sorting by parents according to mobile phone policies or any other changes that occurred in the school. Other permanent student characteristics change slightly pre- and post-ban, with a 5\% decrease in the proportion of minority students and a $5 \%$ and $6 \%$ increase in the proportion of SEN and FSM students, respectively. As these variables are not standardized each year, these differences may reflect general trends in the population. Once the changes over time and the differences across schools are taken into account, there are no significant differences in variables before and after bans are introduced. ${ }^{11}$

Reassuringly these permanent student characteristics are similar for the responding school that never introduced a mobile phone ban. On average students from this school do have higher grades on entry and exit compared to adopting schools. The raw value-added is very similar to the adopting schools pre-policy but lower than the schools post adoption. This, combined with the

\footnotetext{
${ }^{11}$ We estimate the effect of these variables on an indicator variable if a policy has been introduced at that school, conditional on year and school effects. Each characteristic is tested separately and none were found to be significantly correlated. See Table A.1 for results; we find no evidence of sorting based on student characteristics.
} 
increase in age 16 test scores after ban, could be taken as an early indications of the benefits of restricting mobile phone use in schools.

These comparisons are made using the characteristics of the students that we use for the

analysis. However, one may be concerned that the intake of the schools changes once the policy has been introduced which may alter the nature of the schooling environment and hence impact on student test scores. Whilst these potential affects could be interpreted as the total policy impact of a mobile phone ban in a partial equilibrium, with parents sorting between schools with and without bans, the goal of this paper is to estimate the impact of bans in schools that implemented them. To this end, we present series of event studies on the intake of these schools before and after the phone bans conditional on school and year effects in Appendix Figures A.1. The characteristics (gender, FSM, SEN, minority status, age 11 test scores) of students enrolling in their first year of these schools before or after the ban are not significantly different from those enrolling in the year of the ban. There are trends in the type of student not captured by the year effects, but there is no change in the trends with the introduction of the ban. Moreover, the direction of these trends would work against finding an impact of banning policies as the student intakes are increasingly from underperforming groups (increasing rates of FSM, and SEN students and worsening prior test scores).

\subsection{Mobile phone use}

Any impact a school mobile phone ban could have would be tempered if teenagers did not use phones in the first instance. Survey research by the Office of Communications (Ofcom) finds that teenagers in the UK have similar mobile ownership rates as adults since mid-2000s (Ofcom, 2011). Figure 1 shows the percentage of individuals who owned a mobile phone in England between 2000 and 2011. It shows a steady increase in ownership, reaching 94\% in 2011. A further survey of teenagers in 2005 found that $82 \%$ of 12-16 years old owned a mobile phone, being slightly higher than the overall rate of $80 \%$ (Ofcom, 2006). This masks the differential ownership rates amongst teens, there is a large increase in ownership and usage rates occurring between ages 14 and 16. Although there are differences by age, ownership rates do not vary considerably across income groups among UK teenagers (Ofcom, 2011). Therefore despite not having individual phone use data, we are confident that a school introducing a ban would potentially have a large 
impact on the access to phones. Moreover, it needs not be the case for an individual to use a phone to be distracted by them, their use by others in the classroom may cause disruptions.

\section{Empirical strategy}

We estimate the impact of a mobile phone ban on student achievement, exploiting differences in the timing of the introduction of policies across different schools. Equation (1) presents our baseline specification:

$$
Y_{i s t}=\beta_{0}+\beta_{1} \text { Ban }_{s t}+\mu_{s}+\gamma_{t}+\varepsilon_{i s t}
$$

where $Y_{i s t}$ is the test score of student $i$ in high school $s$ in year $t$. Our primary measure of student performance is test score at age $16 .^{12} \mathrm{Ban}_{s t}$ is the indicator variable of interest for whether school $s$ prohibits mobile phones from its premises in time period $t$. Accordingly, the coefficient of interest $\beta_{1}$ captures the impact of the introduction of the mobile phone ban on student test scores, estimated using the within-school variation in test scores over time. We assume there are three components to the error term that are unobservable; $\mu$ is the difference in student performance due to school effects, $\gamma$ represents common shocks to all students in a particular year, and $\varepsilon$ is the idiosyncratic error and contains all of the variation in individual outcomes within a school year.

There may be a concern that only high-achieving schools introduce mobile phone bans, which could lead to overestimating the effects of a mobile phone ban. Similarly, if there was a positive trend in student test scores and mobile phone bans were only introduced in the later periods, some of this growth would be incorrectly attributed to bans. We can account for these two possibilities by allowing for school and year mean achievement to vary through fixed effects. The inclusion of these fixed effects allows for the introduction of mobile phone bans to be non-random, i.e. more likely to occur in schools with low or high test scores, allowing for covariance between Ban $_{s t}$ and $\mu_{s}$ as well as $\gamma_{t}{ }^{13}$

\footnotetext{
${ }^{12}$ We use test score at age 16 as our primary measures of student performance as mobile ownership is higher among older teens and test at age 16 are high stakes exams. We also estimate impacts on achievement level at age 14 in Table 8. Results using achievement level at age 14 are smaller and insignificant.

${ }^{13}$ Note it does not allow for the effect of the ban to vary across schools or student types. Standard errors are clustered at the school level to account for correlations within school overtime. We also tested using percentile-t cluster bootstrap as in Cameron et al (2008) for the main specification. Results were similar.
} 
Specification (1) is restrictive, as it does not allow for differences in student outcomes within a school other than through $\varepsilon_{i s t}$. The individual level panel aspect of the NPD allows us to condition on students' prior performance at the end of primary school $\mathrm{Y}_{\text {ist-1, }}$, accounting for student ability and all school and family investments up until the start of secondary school. This can be seen in specification (2) this changes the interpretation of the $\beta_{1}$ parameter from the increase in test scores due to the ban, to the increase in the gains in test scores due to the ban. In addition to prior achievement, we also condition on a vector of other observable student characteristics, $\mathrm{X}_{\mathrm{i}}$, representing: FSM eligibility, SEN status, gender and ethnicity. The inclusion of these individual controls ostensibly accounts for student sorting to schools on the basis of observable inputs. The extent to which $\beta_{1}$ changes with their inclusion provides us with a gauge for how many students sort to schools based on phone bans.

$$
Y_{i s t}=\beta_{0}+\beta_{1} \text { Ban }_{s t}+\beta_{2} Y_{i s t-1}+\beta_{3} X_{i s t}+\mu_{s}+\gamma_{t}+\varepsilon_{i s t}
$$

A final potential threat arises if there are other positive changes to a school that are correlated with the introduction of a mobile phone ban. Up to this point, we have assumed that school effects are invariant over time; if schools introduced other policies that improved test scores at the same time as a phone ban, this again would lead to overestimating the effect of a ban. To address this, we use survey information to control for any leadership or policy changes that occurred during the period of analysis. OtherPolicy st $_{\text {is }}$ a dummy variable to control for other leadership or policy changes. ${ }^{14}$ In our most demanding specification, we also account for mean peer prior achievement for each student $\bar{Y}_{-i s t-1}$. We know which students are in the same school cohort as student $i$, and it is possible that students affect each other's growth in test scores through peer effects. The inclusion of prior peer achievement and information on other policy and leadership changes, as represented by equation (3), allows us to account for time-variant characteristics of the school.

$$
Y_{i s t}=\beta_{0}+\beta_{1} \text { Ban }_{s t}+\beta_{2} Y_{i s t-1}+\beta_{3} X_{i s t}+\beta_{4} \text { OtherPolicy }_{s t}+\beta_{5} \bar{Y}_{-i s t-1}+\mu_{s}+\gamma_{t}+\varepsilon_{i s t}
$$

\footnotetext{
${ }^{14}$ The variable OtherPolicy $_{s t}$ takes a value of 1 for the years after a change at a school occurs. We combine information coming from our survey of headteachers and information from school's website. We do not observe multiple change of policies/leader in addition to the phone policy change, hence a binary variable can be used.
} 
Finally, we estimate the heterogeneity of the impact of mobile phone bans by student characteristics in a triple differences framework. $\beta_{1 c}$ is the additional difference in student outcomes by binary student characteristic $c$ within schools that implemented a ban in period $t$. We use our most flexible specification (3) above for these estimates and obtain the additional effect of a ban on SEN students, FSM students, males, minorities and by achievement level at age 11 .

$$
\begin{gathered}
Y_{i s t}=\beta_{0}+\beta_{1} \text { Ban }_{s t}+\beta_{1 c} \text { Ban }_{s t} * \text { Characteristic }_{i}+\beta_{2} Y_{i s t-1} \\
+\beta_{3} X_{\text {ist }}+\beta_{4} \text { OtherPolicy }_{s t}+\beta_{5} \bar{Y}_{-i s t-1}+\mu_{s}+\gamma_{t}+\varepsilon_{i s t}
\end{gathered}
$$

\section{Results}

\subsection{Main results}

Table 4 presents estimates of the impact of a mobile phone ban on individual student performance. There are five columns, which account for more potential biases as one moves from left to right. Column 1 is the most basic specification that only accounts for the across-school and across-year mean differences in test scores. Here we find a positive relationship between the introduction of a mobile phone ban and student test scores of 5.67 percent of a standard deviation.

However, we still may be concerned that student sorting by observable or unobservable characteristics may be driving this estimate; columns 2 and 3 include student characteristics in order to account for this. Conditioning on prior performance indicates that the growth in test scores is $0.062 \sigma$, and this increases to $0.065 \sigma$ when other student characteristics are also controlled for.

The last two columns account for time-varying school characteristics. Including an indicator variable, which denotes whether there was a leadership change or other policy change has taken place at the school during the period in year $t$ or later, increases the estimate slightly. Results of our preferred specification (5), which allows for mean peer effects, are marginally smaller, but continue to show an improvement in student performance after a school bans mobile phones. After a ban has been introduced, the average student attending that school has $6.41 \%$ of a standard deviation greater gains in test scores compared to a school that did not introduce a ban. 


\subsection{Heterogeneity}

Table 5 studies the heterogeneity of a ban on students with different characteristics, under a triple differences framework, estimating the additional impact on SEN, FSM, male students and by prior test score. This is in addition to any baseline effects of the ban under specification (5). The results indicate that a mobile phone ban has a positive and significant impact on FSM-eligible students (column 1) and SEN students (column 2). The baseline effect of a mobile phone ban is positive but not statistically significant at the $10 \%$ level in these specifications. The interaction of the ban with prior achievement is negative (column 4), implying that it is predominantly lowability students who gain from a ban. The coefficient of -0.0604 means that students in the top percentile nationally would lose $0.0604 \sigma$ with the introduction of a ban compared to a student in the lowest percentile. However, there is a general positive effect of a ban of $0.0621 \sigma$, and so overall high-achieving students are not harmed by a ban. This is tested formally in the next table. Column 5 additionally includes interactions with FSM and SEN simultaneously; we find that the ability and SEN interaction terms are significant. This is in line with the heterogeneity results, with the most at-risk students gaining the most.

Table 6 examines the relationship of the impact of mobile phone bans by prior achievement in more detail. Students are grouped into five quintiles based on their achievement level at age 11, where group 1 has the lowest level of achievement and group 5 has the highest. Here, the coefficients represent the total effect of a ban by ability quintile. Again we see that low-achieving students gain the most from a ban, and the impact gradually reduces throughout the prior ability distribution. Those in the lowest quintiles gain $0.1423 \sigma$ and $0.0986 \sigma$ respectively after a ban has been introduced. Only the top quintiles do not significantly gain from the policy, but they are also not negatively affected. ${ }^{15}$ This suggests that high prior achieving students are able to concentrate in class regardless of the mobile phone policy in place but low-achieving students are distracted by mobile phone use. This also implies that any negative externalities from phone use does not impact on the high achieving students.

One would expect the impact of a mobile phone ban to vary according to how well it was complied with. We replace the single $B_{s}$ variable with two variables: one for bans with high

\footnotetext{
${ }^{15}$ We reproduced Table 6 by gender: one table for males and one table for females. The results are very similar for both tables, with males and females in low-achieving groups at age 11 gaining the most from a mobile ban.
} 
compliance, HighCompliance st $_{\text {, and one for bans with low compliance, LowCompliance }}$. Table 7 shows the impact of the ban by level of compliance. As expected, we find larger effects in schools that report a high level of compliance with a ban compared to schools where compliance is weak, where there is no statistically significant impact. ${ }^{16}$

As discussed above, mobile phone ownership is higher for older teens and a big increase occurs between age 14 and 16. One would therefore expect the impact of a mobile ban on student test score at age 14 to be smaller. Table 8 replicates Table 4, now estimating the impact on test scores at age 14. We find the impact of the ban remains positive but is smaller and not significant.

\section{Robustness checks}

\subsection{Event study \& Students intake}

As a first robustness, we first check for potential trends in student attainment that were present before the introduction of the ban. Figure 2 plots the impact of bans by exposure length. Estimates for negative exposure refer to the years prior to a ban, where we would expect the ban to have no impact. Using our most preferred specification, we find that bans have significant effects only after they have been implemented. There is a general upward trend in the impact of the ban, which reflects that students have experienced more time in a school with a phone ban in place. ${ }^{17}$ Moreover, there is little evidence that schools were generally improving before introducing a phone ban, as all the years prior to the ban do not have impacts significantly different from zero and are not increasing.

Table A.1 and Figures A.1 investigate different types of potential pupils due to the ban. Table A.1 tests whether the types of students being tested in the high stakes exams are significantly different after a school has introduced a phone ban. Conditional on school and year fixed effects students are no more likely to be male, FSM, SEN, or have high prior achievement after then ban.

\footnotetext{
${ }^{16}$ The compliance measure is coming from our mobile phone survey. Headteachers were asked to rate to what extent the policy was adhered to by students on a seven-point scale (with 1 meaning "not at all" to 7 meaning "completely"). A school was considered to have a high-compliance ban if the response was greater than four. We also created an alternative measure of compliance using punishment at the school after a phone is used. Results were similar and available upon request.

${ }^{17}$ Estimations that directly estimated this additional positive trend failed to find a significant relationship. Given the upward trend found in the treated schools we do not additionally include individual school time trends as this will absorb some of the treatment.
} 
Figure A.1 presents a series of graphs plotting the high school intake before and after ban by pupil characteristics. Even though these students will be five academic years below the students taking the exams, any positive change in their characteristics may reflect an easier workload on teachers in the school. However, Figure A.1 shows that the type of pupil are not sorting to schools due to the mobile phone ban being in place.

\subsection{Placebo tests}

We next check a key assumption of the model, that we obtain unbiased estimates of $\beta_{1}$ as long as $\operatorname{Cov}\left(\operatorname{Ban}_{i s t}, \varepsilon_{i s t}\right)=0$. If schools that introduced a mobile phone ban were improving regardless, then these gains could be falsely attributed to the policy and we would have an upward biased result. We test this by using a placebo treatment, which is generated by turning on the ban dummy two years before it was actually initiated. This placebo intervention should have no significant impact on the gains in student test scores. If there is a positive significant relationship, then there are correlations between the trend and the intervention. Table 9 presents a parallel set of results as Table 4, but with the effects of a placebo intervention. Placebo treatments do not produce significant gains in student test scores. We take this as further evidence that prior trends are not generating these results.

\subsection{More recent prior ability measures}

Thus far we have used age 11 test scores as a measure of prior achievement for student achievement at age 16. However, there is another statutory exam that takes place between these ages. We replicate Table 4 in Table 10 using achievement at age 14 as a measure of ability instead of the age 11 test scores. This has the advantage that it is a more recent measure of student ability, but has the disadvantage that these exams are conducted in secondary school and therefore could also be affected by the ban. To account for this, we only use the age 14 test scores of students attending schools that have not yet implanted a ban. As there is only two years between the age 14 and age 16 exams, this reduces the sample significantly, but also examines the short-run impact of phone bans. ${ }^{18}$ The estimates are very similar to our previous estimates. Conditional on age 14 test

\footnotetext{
${ }^{18}$ Specifications that allowed for the impact of the effect to increase over time, to reflect the extended exposure that students would have to the ban, did not find any significant additional effect after a ban is first introduced.
} 
scores, mobile phone ban improves gains in test scores by $5.86 \%$ of a standard deviation. These results again in part address the issue of pre-trends, as we see that there are significantly larger gains in test scores between age 14 and 16 for students who were attending schools that introduced a ban during that time. This is a small window of time for other effects to occur. If a positive trends were in place in schools prior to this, the age 14 tests scores would be higher and gains in test scores would be accordingly lower. The heterogeneity of these results is replicated conditional on age 14 ability. Table A.2 presents similar results to Table 6 . The estimates by ability have slightly smaller positive effect for the least able students, but these effects are not significantly different from those in Table 6.

\subsection{Alternative outcome measures}

One may be additionally concerned that these results are dependent on the outcome measure that we are using. Therefore, in the appendix we replicate the previous results using a set of outcome variables to establish the robustness of the estimates. The age 16 measure of achievement used so far in this paper is the standardized point score for all exams taken at the end of compulsory schooling. An alternate scoring system, which accounts for the different difficulties for attaining certain grades, is also used and associated tables can be found in the Appendix (Table A.3). The results and conclusion are once again similar. Tables A.4 and A.5 also replicate the heterogeneity table using the alternative age 16 test score measures, reaching the same conclusion. As some students take more GCSEs than others, thereby allowing for higher total test scores, another measure that is sometimes used is the student's total score in their top eight subjects. Any general increase in exams taken over time will be accounted for by the within year standardisation of test scores. In appendix Table A.6, we provide results according to this measure and results are once again similar. This is not our preferred measure as the number of GCSEs taken could itself be an outcome. This is evidence that the ban is not just related to more exams being taken, but higher test scores achieved.

As noted previously, whether a student scores at least a $\mathrm{C}$ on at least five GCSEs, including English and math, is also a recognized measure of achievement used by schools and parents. We derive a binary variable representing whether this standard is met for each student in our sample. This is used as the outcome of interest in the same specifications, and so assumes a linear 
probability model. In our most demanding specification, we find that a ban improves the probability of a student attaining a $\mathrm{C}$ or better on five GCSEs by 2.01 percentage points against a baseline of 38\% students in our sample attaining this level (Table A.7). Finally, we present equivalent results at the school level for attaining 5+ GCSEs (Table A.8), which again shows that schools improve after the introduction of a ban.

Overall, results are robust to alternative specifications and to a set of student characteristics, including different measures of prior achievement and peer effects. These numerous robustness checks provide confidence that mobile phone bans play a role in determining school and student performance.

\section{Conclusion}

This paper investigates the impact of restricting mobile phone use in schools on student productivity. We combine survey data on mobile phone policies in schools in four cities in England with administrative data on student achievement to create a history of student performance in schools. By exploiting differences in implementation dates, our results indicate that there is an improvement in student performance of $6.41 \%$ of a standard deviation in schools that have introduced a mobile phone ban.

The existing literature on the impact of technology in the classroom implies that the unstructured presence of technology has ambiguous impacts on student achievement. We add to this by illustrating that a highly multipurpose technology, such as mobile phones, can have a negative impact on productivity through distraction. Schools that restrict access to mobile phones subsequently experience an improvement in test scores. However, these findings do not discount the possibility that mobile phones could be a useful learning tool if their use is properly structured. Our findings suggest that the presence of mobile phones in schools should not be ignored.

Finally, we find that mobile phone bans have very different effects on different types of students. Banning mobile phones improves outcomes for the low-achieving students $(14.23 \%$ of a standard deviation) the most and has no significant impact on high achievers. The results suggest that low-achieving students are more likely to be distracted by the presence of mobile phones, while high achievers can focus in the classroom regardless of whether phones are present. Given 
heterogeneous results, banning mobile phones could be a low-cost way for schools to reduce educational inequality.

\section{References}

Abouk, R., \& Adams, S. (2013). Texting bans and fatal accidents on roadways: Do they work? Or do drivers just react to announcements of bans? American Economic Journal: Applied Economics, 5(2), 179-199.

Aral, S., E. Brynjolfsson, and M. Van Alstyne (2007). Information, technology and information worker productivity: Task level evidence. National Bureau of Economic Research Working Paper.

Atkinson, A., S. Burgess, B. Croxson, P. Gregg, C. Propper, H. Slater, and D. Wilson (2009). Evaluating the impact of performance-related pay for teachers in England. Labour Economics 16(3), 251-261.

Bandiera, O., Larcinese, V., \& Rasul, I. (2010). Heterogeneous class size effects: New evidence from a panel of university students. The Economic Journal, 120(549), 1365-1398.

Barkham, P. and S. Moss (November 2012). Should mobile phones be banned in schools? The Guardian.

Barrera-Osorio, Felipe, and Leigh L. Linden. 2009. "The Use and Misuse of Computers in Education: Evidence from a Randomized Experiment in Colombia." World Bank Impact Evaluation Series 29, Policy Research Working Paper 4836.

Barrow, L. L. Markman, and C.E. Rouse. (2009) Technology's edge: The educational benefits of computer aided instruction. American Economic Journal: Economic Policy 1 (1): $52-74$

Bartel, A., C. Ichniowski, and K. Shaw (2007). How does information technology affect productivity? Plant-level comparisons of product innovation, process improvement, and worker skills. The Quarterly Journal of Economics 122(4), 1721-1758.

Beland, L.-P. and D. Kim (2014). The effect of high school shootings on schools and student performance. CLSRN Working Paper.

Bergman, P. (2012). The more you know: Evidence from a field experiment on parentchild information frictions and human capital investment. Working Paper - Teachers College Columbia

Berlinski, S., M. Busso, J (2013). Pedagogical change in mathematics teaching: Evidence from a randomized control trial. Columbia Working Papers

Beuermann, D. W., C. McKelvey, and C. Sotelo (2012). The effects of mobile phone infrastructure: Evidence from rural Peru. Banco Central de Reserva del Peru.

Bhargava, S., \& Pathania, V. (2013). Driving under the (cellular) influence. American Economic Journal: Economic Policy, 5(3), 92-125. 
Brynjolfsson, E. (1990). Information technology and the re-organization of work: Theory and evidence.

Burgess, S., D. Wilson, and J. Worth (2013). A natural experiment in school accountability: The impact of school performance information on pupil progress. Journal of Public Economics.

Brau, James \& Fawcett, Stanley (2006), Initial Public Offerings: An Analysis of Theory and Practice, Journal of Finance, 61 (1).

Cameron, A. C., Gelbach, J. B., \& Miller, D. L. (2008). Bootstrap-based improvements for inference with clustered errors. The Review of Economics and Statistics, 90(3), 414-427.

Cameron, A. C., Gelbach, J. B., \& Miller, D. L. (2011). Robust inference with multiway clustering. Journal of Business \& Economic Statistics, 29(2).

Campbell, Scott, R. L. A. L. and K. Purcell (2010). Teens and mobile phones. Pew Research Center Communication studies.

Card, David, Alexandre Mas, Enrico Moretti, and Emmanuel Saez. 2012. "Inequality at Work: The Effect of Peer Salaries on Job Satisfaction." American Economic Review, 102(6): 2981-3003.

Carrell, S. E. and M. L. Hoekstra (2010). Externalities in the classroom: How children exposed to domestic violence affect everyone's kids. American Economic Journal: Applied Economics 2(1), 211-228.

Carrell, S. E., T. Maghakian, and J. E. West (2011). A's from zzzz's? The causal effect of school start time on the academic achievement of adolescents. American Economic Journal: Economic Policy 3(3), 62-81.

Carroll, D. (September 2013). Cleveland teacher uses cell phones as classroom learning tools. WRCB.

Chakraborty, A. and M. Kazarosian (1999). Product differentiation and the use of information technology: New evidence from the trucking industry. NBER Working Paper

Chingos, M. M. (2012). The impact of a universal class-size reduction policy: Evidence from Florida's statewide mandate. Economics of Education Review, 31(5), 543-562.

Cristia, Juilan, P., Ibraranan, S.Cueto, A. Santiago, E. Servein (2012). Technology and child development: Evidence from the One Laptop per Child Program. Inter-American Development Bank Working Paper 304

DiNardo, J. E. and Pischke, J.-S (1997). The returns to computer use revisited: Have pencils changed the wage structure too? The Quarterly Journal of Economics 112(1), 291303.

Ding, W. W., S. G. Levin, P. E., Stephan, and A. E. Winkler (2009). The impact of information technology on scientists' productivity, quality and collaboration patterns. NBER Working Paper

Drury, E. (September 2012). Mobile phones in the classroom: Teachers share their tips. The Guardian, Guardian Professional. 
Fairlie, R. W. and J. Robinson (2013). Experimental evidence on the effects of home computers on academic achievement among schoolchildren. American Economic Journal: Applied Economics 5(3), 211-240.

Fiorini, M. (2010). The effect of home computer use on children's cognitive and noncognitive skills. Economics of Education Review 29(1), 55-72.

Fryer Jr., R. G. (2013). Information and student achievement: Evidence from a cellular phone experiment. NBER Working Paper

Gibbons, S., S. Machin, and O. Silva (2008). Choice, competition, and pupil achievement. Journal of the European Economic Association, 6(4), 912-947.

Hall, Robert E., and Alan B. Krueger. 2012. "Evidence on the Incidence of Wage Posting, Wage Bargaining, and On-the-Job Search." American Economic Journal: Macroeconomics, 4(4): 56-67.

Heffetz, Ori (2011), A Test of Conspicuous Consumption: Visibility and Income Elasticities, Review of Economics and Statistics, 93(4): 1101-1117

Hoffmann, F., \& Oreopoulos, P. (2009). Professor qualities and student achievement. Review of Economics and Statistics, 91(1), 83-92.

Johnson, S. (October 2012). Teachers 'tactically' ignore mobile phone use in classroom. The Telegraph.

Krueger, A. B. (1993). How computers have changed the wage structure: Evidence from microdata, 1984-1989. The Quarterly Journal of Economics, 108(1), 33-60.

Lavy, V., M. D. Paserman, and A. Schlosser (2012). Inside the black box of ability peer effects: Evidence from variation in the proportion of low achievers in the classroom*. The Economic Journal, 122(559), 208-237.

Lee, Y., Atkinson, C., Hritsko, D., \& Acquaah, K. (2014) The Effects of Cell Phone Distraction on Cognitive Tasks.. Working paper

Lenhart, A. (2009) Teens and Mobile Phones over the Past Five Years: Pew Internet Looks Back. Pew Research Center

Levine L. E., B. M. Waite, and L. L. Bowman. (2013) Use of instant messaging predicts self-report but not performance measures of inattention, impulsiveness, and distractibility. Cyberpsychology, Behavior, and Social Networking. 16(12): 898-903.

Luyten, H., J. Peschar, and R. Coe (2008). Effects of schooling on reading performance, reading engagement, and reading activities of 15-year-olds in England. American Educational Research Journal 45(2), 319-342.

M. Koutamanis, H. G. M. Vossen, J. P. and P. M. Valkenburg (2013). Practice makes perfect: The longitudinal effect of adolescents instant messaging on their ability to initiate offline friendships. Computers in Human Behaviour, 29(6), 2265 - 2272.

Machin, S., S. McNally, and O. Silva (2007). New technology in schools: Is there a payoff?*. The Economic Journal, 117(522), 1145-1167.

Machin, S. and J. Vernoit (2011). Changing school autonomy: Academy schools and 
their introduction to England's education. Centre for the Economics of Education Discussion Paper 123.

Madden, M, Lenhart A, Duggan M, Cortesi S and Gasser U, (2013) Teens and Technology 2013, Pew Research Center

Malamud, O. and C. Pop-Eleches (2011). Home computer use and the development of human capital. The Quarterly Journal of Economics, 126(2), 987-1027.

Murphy, R. and F. Weinhardt (2013). Top of the class: The importance of rank position. Centre for the Economics of Education Discussion Paper 1241.

Ophir, E., Nass, C., \& Wagner, A. D. (2009). Cognitive control in media multitaskers. Proceedings of the National Academy of Sciences, 106(37), 15583-15587.

Ofcom (2006) Media Literacy Audit: Report on media literacy amongst children. Ofcom Report.

Ofcom (2011). A nation addicted to smartphones. Ofcom report.

O’Toole, M. (Mai 2011). Toronto district school board to lift cell phone ban. National Post.

Reporters (26 Nov 2012). Students thrive as head bans mobile phones. The Telegraph.

Roach, S. S. (1987). The technology slump: Dim prospects from the bottom. Economics Perspective Memorandum.

Roach, S. S. and M. Stanley (1987). America's technology dilemma: A profile of the information economy. Morgan Stanley.

Sandoval, Edgar, Dale Eisinger and Reuven Blau. (2015), Department of Education lifts ban on cell phones in New York City schools, New York Daily News.

Services, E. M. (2013b). UK teens far outshine us counterparts in smartphone usage. $E$ Marketer newsletter.

Services, E. M. (December 2010). 2010 digital marketer report. E-Marketer report.

Services, E. M. (March 2013a). 2013 digital marketer report. E-Marketer report.

Slater, H., N. M. Davies, and S. Burgess (2012). Do teachers matter? Measuring the variation in teacher effectiveness in England. Oxford Bulletin of Economics and Statistics, 74(5), 629-645.

Smith, T. S., M. I. Isaak, C. G. Senette, and B. G. Abadie. Effects of cell-phone and textmessage distractions on true and false recognition. Cyberpsychology, Behavior, and Social Networking. June 2011, 14(6): 351-358. 
Figure 1: Mobile Phone Ownership Rates in England

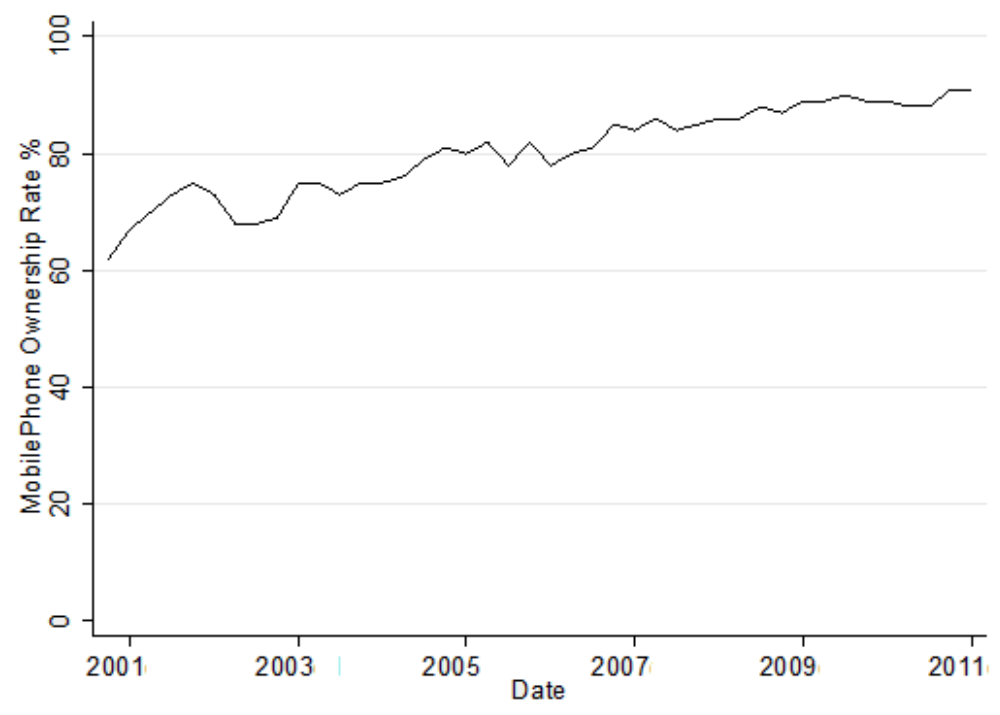

Notes: Phone ownership rates in England amongst individuals 13 years and older. Sources: Oftel/Ofcom, based on face-to-face survey data, 2011 
Figure 2: Impact of Phone Ban by Years of Exposure

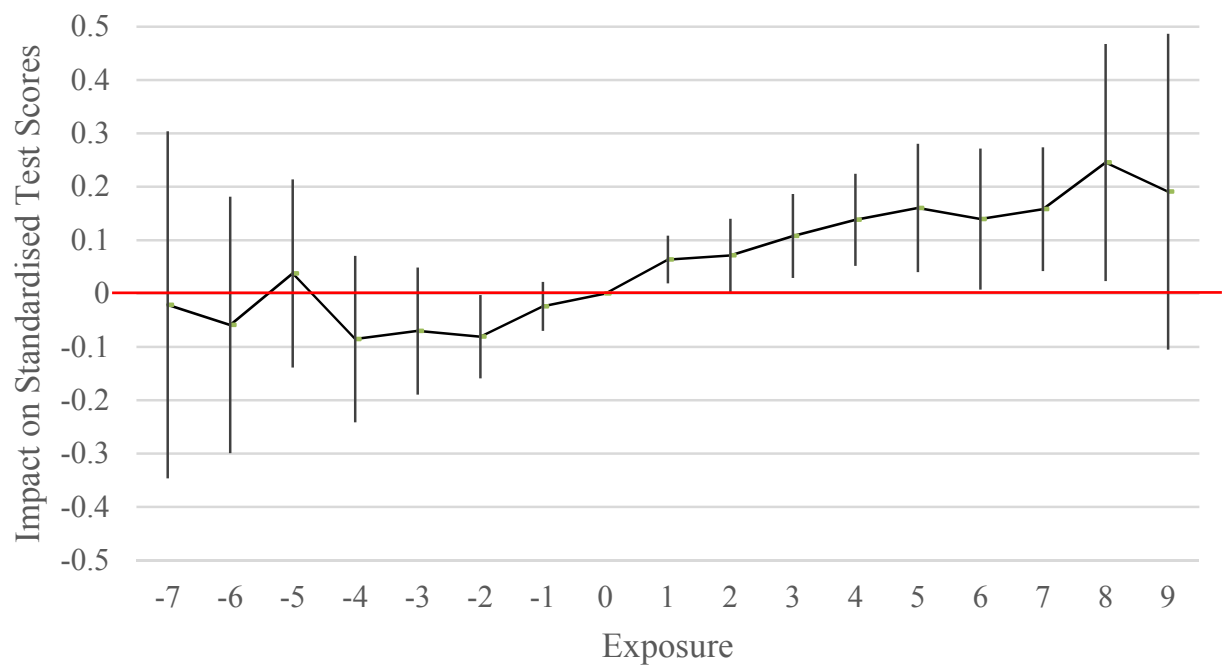

Notes: Estimated impact on age 16 standardised test scores of mobile phone ban by years of exposure, conditional on school and year effects, age 11 test scores and pupil characteristics. Reference year is the year prior to introduction. Error bars represent the $95 \%$ confidence intervals with robust standard errors clustered at the school level. Sources: National Pupil Data Base and author-conducted mobile phone policy survey of schools in four cities in England: Birmingham, Leicester, London and Manchester. 
Table 1: Descriptive Statistics for Key Variables - Representativeness of Sample

\begin{tabular}{lcccc}
\hline Student Characteristics & $\begin{array}{c}\text { All Students in } \\
\text { England }\end{array}$ & $\begin{array}{c}\text { Students in } \\
\text { Sampled Cities }\end{array}$ & $\begin{array}{c}\text { Students in } \\
\text { Responding } \\
\text { Schools }\end{array}$ & $\begin{array}{c}\text { Difference Between } \\
\text { Responding Schools } \\
\text { and Schools in } \\
\text { Surveyed } \\
\text { Cities }\end{array}$ \\
\hline Test scores: Age 16 & 0.000 & 0.013 & 0.071 & 0.069 \\
Test scores: Age 11 & $(1.000)$ & $(1.018)$ & $(0.937)$ & $(0.041)$ \\
Male & 0.000 & -0.034 & -0.094 & -0.072 \\
Minority & $(1.000)$ & $(1.011)$ & $(1.007)$ & $(0.044)$ \\
SEN & 0.506 & 0.502 & 0.467 & -0.042 \\
FSM & $(0.500)$ & $(0.5)$ & $(0.499)$ & $(0.032)$ \\
Total students & 0.182 & 0.454 & 0.593 & 0.166 \\
& $(0.386)$ & $(0.498)$ & $(0.491)$ & $(0.04)$ \\
& 0.146 & 0.166 & 0.181 & 0.018 \\
& $(0.353)$ & $(0.372)$ & $(0.385)$ & $(0.011)$ \\
& 0.162 & 0.239 & 0.308 & 0.082 \\
& $(0.368)$ & $(0.427)$ & $(0.462)$ & $(0.022)$ \\
\hline
\end{tabular}

Notes: Table 2 presents descriptive statistics for key variables for all schools, schools in city surveyed, schools in sample and difference between schools in sample and in city surveyed. SEN means special educational needs students and FSM means Free School Meal students. Sources: National Pupil Database (NPD) and author-conducted mobile phone survey. 
Table 2: Descriptive Statistics on Mobile Phone Policies

\begin{tabular}{cccc}
\hline Year & Mobile Bans & $\begin{array}{c}\text { High-compliance } \\
\text { Bans }\end{array}$ & $\begin{array}{c}\text { Low-compliance } \\
\text { Bans }\end{array}$ \\
\hline 2000 & 0 & 0 & 0 \\
2001 & 0 & 0 & 0 \\
2002 & 3 & 2 & 1 \\
2003 & 6 & 5 & 1 \\
2004 & 9 & 7 & 2 \\
2005 & 19 & 13 & 6 \\
2006 & 29 & 20 & 9 \\
2007 & 43 & 31 & 12 \\
2008 & 58 & 38 & 20 \\
2009 & 71 & 47 & 31 \\
2010 & 85 & 54 & 33 \\
2011 & 88 & 55 & 34 \\
2012 & 90 & 56 & \\
\hline
\end{tabular}

Notes: Table depicts the number of mobile phone bans in our sample each year. Headteachers were asked what their phone policy is and when it was introduced. A phone ban is classified as 1) A complete ban of mobile phones on school grounds; or 2) Students hand all phones in at the start of school. Headteachers were asked to rate the extent to which the policy is adhered to by students on a seven-point scale with 1 representing "Not at all" and 7 representing "Completely." A school was considered to have a highcompliance ban if the response was greater than four. Sources: Author-conducted mobile phone policy survey of schools in four cities in England: Birmingham, Leicester, London and Manchester. 
Table 3: Descriptive Statistics on Key Variables Pre- and Post-Policy

\begin{tabular}{lcccccc}
\hline Student Characteristics & $\begin{array}{c}\text { Students } \\
\text { in } \\
\text { Sampled } \\
\text { Cities }\end{array}$ & $\begin{array}{c}\text { Students } \\
\text { in } \\
\text { Responding } \\
\text { Schools }\end{array}$ & $\begin{array}{c}\text { Pre Phone } \\
\text { Ban }\end{array}$ & $\begin{array}{c}\text { Post Phone } \\
\text { Ban }\end{array}$ & $\begin{array}{c}\text { Pre-Post } \\
\text { Difference }\end{array}$ & $\begin{array}{c}\text { Never Ban } \\
\text { Phone }\end{array}$ \\
\hline \multirow{2}{*}{ Test scores: Age 16 } & 0.0130 & 0.0710 & 0.0200 & 0.1168 & 0.0931 & 0.1400 \\
& $(1.0181)$ & $(0.9369)$ & $(0.9566)$ & $(0.9159)$ & $(0.0389)$ & $(0.9261)$ \\
Test scores: Age 11 & -0.0339 & -0.0937 & -0.107 & -0.0845 & 0.0186 & 0.0187 \\
Male & $(1.0109)$ & $(1.007)$ & $(1.0092)$ & $(1.0062)$ & $(0.0413)$ & $(0.9542)$ \\
Minority & 0.5022 & 0.4674 & 0.4659 & 0.4668 & -0.0013 & 0.5345 \\
SEN & $(0.500)$ & $(0.4989)$ & $(0.4988)$ & $(0.4989)$ & $(0.0243)$ & $(0.4989)$ \\
FSM & 0.656 & 0.741 & 0.7669 & 0.7151 & -0.0526 & 0.7917 \\
& $(0.475)$ & $(0.4381)$ & $(0.4228)$ & $(0.4514)$ & $(0.0251)$ & $(0.4062)$ \\
& 0.1657 & 0.1806 & 0.1527 & 0.2061 & 0.0519 & 0.2023 \\
Total students & $(0.3719)$ & $(0.3847)$ & $(0.3597)$ & $(0.4045)$ & $(0.0126)$ & $(0.4018)$ \\
& 0.2406 & 0.3138 & 0.2801 & 0.3473 & 0.0682 & 0.2488 \\
& $(0.4274)$ & $(0.464)$ & $(0.4491)$ & $(0.4761)$ & $(0.0177)$ & $(0.4324)$ \\
& & & & & & 2002 \\
\hline
\end{tabular}

Notes: Table 3 presents descriptive statistics for key variables pre- and post-policy and for all schools and schools in the city surveyed. SEN means special educational needs students and FSM means Free School Meal students. Sources: National Pupil Database (NPD) and author-conducted mobile phone survey. 
Table 4: Effect of Mobile Bans on Student Performance

Age 16 Test Scores

Mobile ban

Mobile ban

Prior test scores: Age 11

Student characteristics

Other policy changes

Prior peer achievement

School effects

Year effects

Observations
(1)

(2)

(3)

(4)

(5)
$0.0654 *$

$(0.0361)$

(0.0357)

$\checkmark$

$\begin{array}{ll} & \checkmark \\ & \\ & \\ & \\ \checkmark & \checkmark \\ \checkmark & \checkmark\end{array}$

$130,482 \quad 130,482$
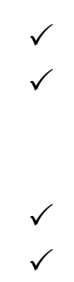

130,482
$0.0669^{*}$

(0.0368)

$0.0641^{*}$

(0.0373)

Notes: Table 4 presents regression estimates for student performance. The outcome variable is the standardized test score at age 16. We use robust clustered standard errors at the school level with school and year fixed effects. Student characteristics are controlled for whether a student is male, a minority, SEN or FSM. SEN means special educational needs students and FSM means Free School Meal students. The "Other policy changes" variable controls for whether there was a leadership or policy changes occurring at the time of the introduction of a mobile phone ban. ${ }^{* * *} \mathrm{p}<0.01,{ }^{* *} \mathrm{p}<0.05, * \mathrm{p}<0.1$. Sources: National Pupil Database (NPD) and author-conducted mobile phone survey. 
Table 5: The Effect of Mobile Phone Bans on Student Performance by Student Characteristics

\begin{tabular}{|c|c|c|c|c|c|}
\hline Age 16 Test Scores & (1) & (2) & (3) & (4) & (5) \\
\hline \multirow[t]{2}{*}{ Mobile ban } & 0.0432 & 0.0457 & 0.0445 & $0.0621^{*}$ & 0.0405 \\
\hline & $(0.0385)$ & $(0.0393)$ & $(0.0397)$ & $(0.0374)$ & $(0.0405)$ \\
\hline \multirow[t]{2}{*}{ Mobile ban * FSM } & $0.0658 * *$ & & & & 0.0382 \\
\hline & $(0.0282)$ & & & & $(0.026)$ \\
\hline \multirow[t]{2}{*}{ Mobile ban * SEN } & & $0.1100^{* * *}$ & & & $0.0591^{*}$ \\
\hline & & $(0.0327)$ & & & $(0.0329)$ \\
\hline \multirow[t]{2}{*}{ Mobile ban * Male } & & & 0.0424 & & \\
\hline & & & $(0.0389)$ & & \\
\hline \multirow{3}{*}{$\begin{array}{l}\text { Mobile ban * Prior test } \\
\text { scores: Age } 11\end{array}$} & & & & & \\
\hline & & & & $-0.0604 * * *$ & $-0.0488 * * *$ \\
\hline & & & & $(0.0133)$ & $(0.0129)$ \\
\hline Prior test scores: Age 11 & $\checkmark$ & $\checkmark$ & $\checkmark$ & $\checkmark$ & $\checkmark$ \\
\hline Student characteristics & $\checkmark$ & $\checkmark$ & $\checkmark$ & $\checkmark$ & $\checkmark$ \\
\hline Other policy changes & $\checkmark$ & $\checkmark$ & $\checkmark$ & $\checkmark$ & $\checkmark$ \\
\hline Prior peer achievement & $\checkmark$ & $\checkmark$ & $\checkmark$ & $\checkmark$ & $\checkmark$ \\
\hline School effects & $\checkmark$ & $\checkmark$ & $\checkmark$ & $\checkmark$ & $\checkmark$ \\
\hline Year effects & $\checkmark$ & $\checkmark$ & $\checkmark$ & $\checkmark$ & $\checkmark$ \\
\hline Observations & 130,482 & 130,482 & 130,482 & 130,482 & 130,482 \\
\hline
\end{tabular}

Notes: Table 5 presents regression estimates for student performance. The outcome variable is the standardized test score in a student's eight best subjects. We use robust clustered standard errors at the school level with school and year fixed effects. Student characteristics are controlled for using indicators for whether the student was male, a minority, SEN and FSM. SEN means special educational needs students and FSM means Free School Meal students. The "Other policy changes" variable controls for whether there was a leadership or policy changes occurring at the time of the introduction of a mobile phone ban. ${ }^{* * *} \mathrm{p}<0.01, * * \mathrm{p}<0.05,{ }^{*} \mathrm{p}<0.1$. Sources: National Pupil Database (NPD) and author-conducted mobile phone survey. 


\section{Table 6: The Effect of Mobile Phone Bans on Student Performance by Prior performance}

\begin{tabular}{lcccc}
\hline Age 16 Test Scores & $(1)$ & $(2)$ & $(3)$ & $(4)$ \\
\hline & & & & \\
Impact by age 11 test scores & & & & \\
Mobile ban * 1st Quintile & $0.1306^{* * *}$ & $0.1421^{* * *}$ & $0.1444^{* * *}$ & $0.1423^{* * *}$ \\
& $(0.0389)$ & $(0.0396)$ & $(0.0402)$ & $(0.0404)$ \\
Mobile ban * 2nd Quintile & $0.0868^{* *}$ & $0.0984^{* *}$ & $0.1007^{* *}$ & $0.0986^{* *}$ \\
& $(0.0385)$ & $(0.0389)$ & $(0.0398)$ & $(0.0401)$ \\
Mobile ban * 3rd Quintile & 0.0566 & $0.0659^{*}$ & $0.0677^{*}$ & 0.0654 \\
& $(0.0389)$ & $(0.0395)$ & $(0.0402)$ & $(0.0409)$ \\
Mobile ban * 4th Quintile & 0.0275 & 0.0245 & 0.026 & 0.0229 \\
& $(0.0399)$ & $(0.0396)$ & $(0.0403)$ & $(0.0409)$ \\
Mobile ban * 5th Quintile & -0.0118 & -0.0224 & -0.0216 & -0.0254 \\
& $(0.0412)$ & $(0.0422)$ & $(0.0428)$ & $(0.0429)$ \\
& & & & \\
Test scores: Age 11 & $\checkmark$ & $\checkmark$ & $\checkmark$ & $\checkmark$ \\
categorical & & & & $\checkmark$ \\
Student characteristics & & $\checkmark$ & $\checkmark$ & $\checkmark$ \\
Other policy changes & & & $\checkmark$ & $\checkmark$ \\
Prior peer achievement & $\checkmark$ & $\checkmark$ & $\checkmark$ & $\checkmark$ \\
School effects & $\checkmark$ & & & \\
Year effects & & 130,482 & 130,482 & 130,482 \\
& & & &
\end{tabular}

Notes: Table 6 presents regression estimates for student performance. The outcome variable is the standardized test score in a student GCSE exams. We use robust clustered standard errors at the school level with school and year fixed effects. Student characteristics are controlled for whether a student is male, a minority, SEN or FSM. SEN means Special Educational Needs students and FSM means Free School Meal students. Key Stage 2 represents standardized test scores at age 11. In this table, student are divided into quintiles based on their achievement level at age 11, where group 1 is the lowest-achieving group and group 5 is the highest-achieving group. The "Other policy changes" variable controls for whether there was a leadership or policy changes occurring at the time of the introduction of a mobile phone ban. ${ }^{* * *} \mathrm{p}<0.01,{ }^{* *} \mathrm{p}<0.05,{ }^{*} \mathrm{p}<0.1$. Sources: National Pupil Database (NPD) and author-conducted mobile phone survey. 
Table 7: The Effect of Mobile Phone Bans on Student Performance by Ban Compliance

\begin{tabular}{lccccc}
\hline Age 16 Test Scores & $(1)$ & $(2)$ & $(3)$ & $(4)$ & $(5)$ \\
\hline High Compliance mobile ban & $0.0619^{*}$ & $0.0668^{*}$ & $0.0699^{*}$ & $0.0717^{* *}$ & $0.0692^{*}$ \\
& $(0.0402)$ & $(0.0403)$ & $(0.0405)$ & $(0.0413)$ & $(0.0413)$ \\
Low Compliance mobile ban & 0.0159 & 0.0233 & 0.0294 & 0.0298 & 0.0241 \\
& $(0.1109)$ & $(0.1058)$ & $(0.1051)$ & $(0.1055)$ & $(0.1079)$ \\
& & & & & \\
Prior test scores: Age 11 & & $\checkmark$ & $\checkmark$ & $\checkmark$ & $\checkmark$ \\
Student characteristics & & & $\checkmark$ & $\checkmark$ & $\checkmark$ \\
Other policy changes & & & & $\checkmark$ & $\checkmark$ \\
Prior peer achievement & $\checkmark$ & $\checkmark$ & $\checkmark$ & $\checkmark$ & $\checkmark$ \\
School effects & $\checkmark$ & $\checkmark$ & $\checkmark$ & $\checkmark$ & $\checkmark$ \\
Year effects & & & & & \\
& & & & & \\
Observations & 130,482 & 130,482 & 130,482 & 130,482 & 130,482 \\
& & & & & \\
\hline
\end{tabular}

Notes: Table 7 presents regression estimates for student performance. It separates bans into high-compliance (principal assessment score above 4 out of 7) and low-compliance mobile bans. The outcome variable is the standardized test score at age 16. We use robust clustered standard errors at the school level with school and year fixed effects. Student characteristics are controlled for whether a student is male, a minority, SEN or FSM. SEN means Special Educational Needs students and FSM means Free School Meal students. The "Other policy changes" variable controls for whether there was a leadership or policy changes occurring at the time of the introduction of a mobile phone ban. ${ }^{* * *} \mathrm{p}<0.01,{ }^{* *} \mathrm{p}<0.05,{ }^{*} \mathrm{p}<0.1$ Sources: National Pupil Database (NPD) and author-conducted mobile phone survey. 
Table 8: Effect of Mobile Bans on Student Performance at Age 14

Age 14 Test Scores

(1)

(2)

(3)

(4)

(5)

Mobile ban

0.0077

(0.0187)

0.0231

(0.0175)

\begin{abstract}
0.0268
\end{abstract}
(0.0176)

0.026

(0.0177)

0.0245

(0.0173)

Prior test scores: Age 11

Student characteristics

Other policy changes

Prior peer achievement

School effects

Year effects

Observations

$\begin{array}{ll} & \checkmark \\ & \\ & \\ & \\ \checkmark & \checkmark \\ \checkmark & \checkmark\end{array}$

112,212

$\begin{array}{ll}\checkmark & \checkmark \\ & \checkmark \\ & \\ & \\ \checkmark & \checkmark \\ & \checkmark\end{array}$

112,212
112,212

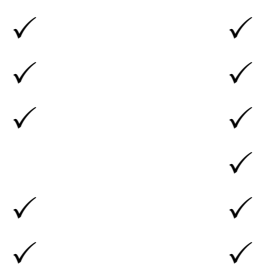

112,212
112,212

Notes: Table 8 presents regression estimates for student performance at age 14. The outcome variable is the standardized test score at age 14. We use robust clustered standard errors at the school level with school and year fixed effects. Student characteristics are controlled for based on whether the student is a male, a minority, SEN or FSM. SEN means Special Educational Needs students and FSM means Free School Meal students. The "Other policy changes" variable controls for whether there was a leadership or policy changes occurring at the time of the introduction of a mobile phone ban. $* * * \mathrm{p}<0.01, * * \mathrm{p}<0.05,{ }^{*} \mathrm{p}<0.1$ Sources: National Pupil database (NPD) and author-conducted mobile phone survey. 
Table 9: Effect of Placebo Mobile Bans on Student Performance

Age 16 Test Scores

(1)

(2)

(3)

(4)

(5)

Placebo mobile ban

\begin{abstract}
0.0288
\end{abstract}
$(0.0525)$

0.0296

$(0.0503)$

0.0240

$(0.0518)$

0.0335

$(0.0501)$

0.0326

$(0.0512)$

Prior test scores: Age 11

Student characteristics

Other policy changes

Prior peer achievement

School effects

Year effects

Observations

130,482

$\checkmark \quad \checkmark$

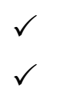

$\checkmark$

$\checkmark$

$\checkmark$

$\checkmark$

$\checkmark$

Notes: Table 9 presents regression estimates for student performance. A placebo ban is introducing the ban two years before it was actually introduced. The outcome variable is the standardized test score at age 16 . We use robust clustered standard errors at the school level with school and year fixed effects. Student characteristics are controlled for whether a student is male, a minority, SEN or FSM. SEN means Special Educational Needs students and FSM means Free School Meal students. The "Other policy changes" variable controls for whether there was a leadership or policy changes occurring at the time of the introduction of a mobile phone ban. ${ }^{* * *} \mathrm{p}<0.01,{ }^{*} \mathrm{p}<0.05, * \mathrm{p}<0.1$. Sources: National Pupil Database (NPD) and authorconducted mobile phone survey. 
Table 10: Effect of Mobile Bans on Student Performance Conditioning on Age 14 Test Scores

\begin{tabular}{lccccc}
\hline Age 16 Test Scores & $(1)$ & $(2)$ & $(3)$ & $(4)$ & $(5)$ \\
\hline & & & & & \\
Mobile ban & $0.0655^{*}$ & $0.0535^{*}$ & $0.0599^{*}$ & $0.0598^{*}$ & $0.0586^{*}$ \\
& $(0.0376)$ & $(0.0333)$ & $(0.0333)$ & $(0.0336)$ & $(0.0341)$ \\
& & & & $\checkmark$ \\
Prior test scores: Age 14 & & $\checkmark$ & $\checkmark$ & $\checkmark$ & $\checkmark$ \\
Student characteristics & & & $\checkmark$ & $\checkmark$ & $\checkmark$ \\
Other policy changes & & & & $\checkmark$ & $\checkmark$ \\
Peer characteristics & $\checkmark$ & $\checkmark$ & $\checkmark$ & $\checkmark$ & $\checkmark$ \\
School effects & $\checkmark$ & $\checkmark$ & & & $\checkmark 3,211$ \\
Year effects & & & & & $\checkmark$ \\
& & & & & \\
Observations & 83,211 & & & \\
\end{tabular}

Notes: Table 10 presents regression estimates for student performance. The outcome variable is the standardized test score at age 16 and control for standardized test score at age 14. Estimated on the sample of students who had not been exposed to the ban when examined at age 14 . We use robust clustered standard errors at the school level with school and year fixed effects. Student characteristics are controlled for whether a student is male, a minority, SEN or FSM. SEN means Special Educational Needs students and FSM means Free School Meal students. The "Other policy changes" variable controls for whether there was a leadership or policy changes occurring at the time of the introduction of a mobile phone ban. ${ }^{* * *} \mathrm{p}<0.01,{ }^{* *} \mathrm{p}<0.05, * \mathrm{p}<0.1$ Sources: National Pupil Database (NPD) and author-conducted mobile phone survey. 


\section{Appendix A}

Mobile Phone Survey Questionnaire

Question 1.1) What best describes the school's current mobile phone policy?

a) Complete ban of mobile phones on school grounds

b) Allowed on grounds, but must be turned off

c) Allowed on grounds, but must be turned to silent and off during classes

d) Allowed on grounds, but must be turned to silent at all times

e) Allowed on grounds, but must be considerate with use

f) Other

g) None

Question 1.2) If Other, could you please briefly describe current policy.

Note: Only Answer: Hand into reception, and collected at end of day.

Question 1.3) When was the current policy first introduced?

Question 1.4) What are the punishments for misuse of phones on school grounds?

Question 1.5) Out of 7, to what extent would you say the policy is adhered to by students?

[With 7 being "Completely" and 1 being "Not at all"]

Question 2) Was there a different policy in place before this? - Yes/No

If Yes, please answer the following.

If No, please skip to question 4 .

In the space below, please answer questions 1.2 to 1.5 for this pervious policy (brief description of policy/introduction date/punishments/adherence).

Question 3) Was there a different policy in place before this? - Yes/No

If Yes, please answer the following.

If No, please skip to Question 4.

In the space below, please answer questions 1.2 to 1.5 for this previous policy (brief description of policy/introduction date/punishments/adherence).

Question 4) Were there any other policy or leadership changes at the same time as the mobile policy change?

Question 5) Do you have any other comments? 


\section{Figures A.1}
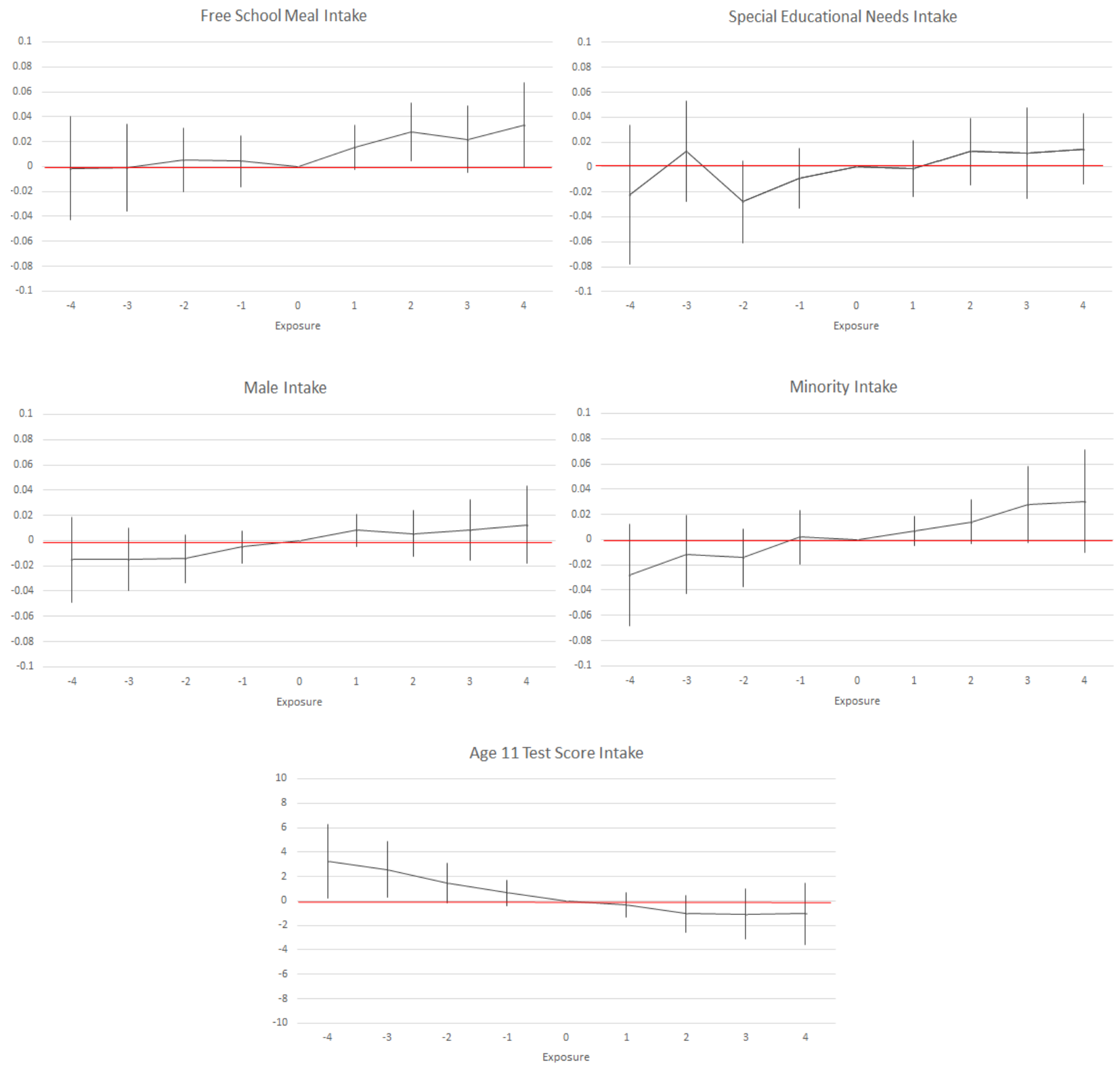

Notes: Estimated impact of mobile phone ban on school intake at age 11, by pupil characteristics conditional on year and school effects. Reference year is the year prior to introduction. Error bars represent the $95 \%$ confidence intervals with robust standard errors clustered at the school level. Sources: National Pupil Data Base and author-conducted mobile phone policy survey of schools in four cities in England: Birmingham, Leicester, London and Manchester. 
Table A.1: Balancing Test

\begin{tabular}{lccccc}
\hline Variables & $\begin{array}{c}\text { Age 11 Student } \\
\text { Performance }\end{array}$ & Male & Minority & SEN & FSM \\
\hline Mobile ban & -0.0094 & -0.0042 & -0.0005 & 0.0096 & 0.0053 \\
& $(0.0124)$ & $(0.0043)$ & $(0.0072)$ & $(0.0101)$ & $(0.0061)$ \\
Observations & 130,482 & 130,482 & 130,482 & 130,482 & 130,482
\end{tabular}

Notes: Table A.1 presents regression estimates for different outcome variables to investigate whether schools that impose a ban are different and if students are sorting into schools based on student characteristics. SEN means the proportion of students that are Special Educational Needs students and FSM means the proportion of students that are Free School Meal students. Male and Minority are the proportion of students that are male or from a minority group, respectively. We use robust clustered standard errors at the school level with school and year fixed effects. ${ }^{* * *} \mathrm{p}<0.01,{ }^{*} \mathrm{p}<0.05,{ }^{*} \mathrm{p}<0.1$ Sources: National Pupil Database (NPD) and authorconducted mobile phone survey. 
Table A.2: Effect of Mobile Bans on Student Performance by Prior Achievement Group Age 14

\begin{tabular}{|c|c|c|c|c|}
\hline Age 16 Test Scores & (1) & (2) & (3) & (4) \\
\hline \multicolumn{5}{|l|}{ Impact by age 14 test scores } \\
\hline Mobile ban*1st Quintile & $\begin{array}{c}0.1015^{* * *} \\
(0.0353)\end{array}$ & $\begin{array}{c}0.1100^{* * *} \\
(0.0351)\end{array}$ & $\begin{array}{c}0.1118^{* * *} \\
(0.0355)\end{array}$ & $\begin{array}{c}0.1046^{* * *} \\
(0.0368)\end{array}$ \\
\hline Mobile ban * 2nd Quintile & $\begin{array}{c}0.0935^{* *} \\
(0.036)\end{array}$ & $\begin{array}{c}0.1074 * * * \\
(0.0358)\end{array}$ & $\begin{array}{c}0.1095 * * * \\
(0.0367)\end{array}$ & $\begin{array}{c}0.1032 * * * \\
(0.0378)\end{array}$ \\
\hline Mobile ban * 3rd Quintile & $\begin{array}{l}0.0551 \\
(0.038)\end{array}$ & $\begin{array}{c}0.0615 \\
(0.0382)\end{array}$ & $\begin{array}{c}0.0638 \\
(0.0393)\end{array}$ & $\begin{array}{c}0.0564 \\
(0.0394)\end{array}$ \\
\hline Mobile ban * 4th Quintile & $\begin{array}{l}0.0213 \\
(0.039)\end{array}$ & $\begin{array}{c}0.0223 \\
(0.0387)\end{array}$ & $\begin{array}{l}0.0246 \\
(0.04)\end{array}$ & $\begin{array}{c}0.0178 \\
(0.0406)\end{array}$ \\
\hline Mobile ban * 5th Quintile & $\begin{array}{r}-0.0072 \\
(0.044)\end{array}$ & $\begin{array}{c}-0.0014 \\
(0.0449)\end{array}$ & $\begin{array}{c}0.0016 \\
(0.0463)\end{array}$ & $\begin{array}{c}-0.0027 \\
(0.0463)\end{array}$ \\
\hline Test scores: Age 14 categorical & $\checkmark$ & $\checkmark$ & $\checkmark$ & $\checkmark$ \\
\hline Student characteristics & & $\checkmark$ & $\checkmark$ & $\checkmark$ \\
\hline Other policy changes & & & $\checkmark$ & $\checkmark$ \\
\hline Peer characteristics & & & & $\checkmark$ \\
\hline School effects & $\checkmark$ & $\checkmark$ & $\checkmark$ & $\checkmark$ \\
\hline Year effects & $\checkmark$ & $\checkmark$ & $\checkmark$ & $\checkmark$ \\
\hline Observations & 83,211 & 83,211 & 83,211 & 83,211 \\
\hline
\end{tabular}

Notes: Table A.2 presents regression estimates for student performance. The outcome variable is the standardized test score. We use robust clustered standard errors at the school level with school and year fixed effects. Student characteristics are controlled for whether a student is male, a minority, SEN or FSM. SEN means Special Educational Needs students and FSM means Free School Meal students. In this table, students are grouped into five categories based on their achievement level at age 14, where group 1 is the lowest-achieving group and group 5 is the highestachieving group. The "Other policy changes" variable controls for whether there was a leadership or policy changes occurring at the time of the introduction of a mobile phone ban. ${ }^{* * *} \mathrm{p}<0.01,{ }^{* *} \mathrm{p}<0.05,{ }^{*} \mathrm{p}<0.1$ Sources: National Pupil Database (NPD) and author-conducted mobile phone survey. 


\section{Table A.3: Effect of Mobile Bans on Student Performance}

Age 16 Alternate Test Scores

(1)

(2)

(3)

(4)

(5)

Mobile ban

0.0532

(0.0335)

$0.0588 *$

$(0.0328)$

$\checkmark$

Prior test scores: Age 11

Student characteristics

Other policy changes

Peer characteristics

School effects

Year effects

\section{Observations}

130,482
$0.0618^{*}$

$0.0627 *$

(0.0338)
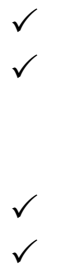

130,482

130,482

130,482

Notes: Table A.3 presents regression estimates for student performance. The outcome variable is the standardized test score at age 16. We use robust clustered standard errors at the school level with school and year fixed effects. Student characteristics are controlled for based on whether the student is male, a minority, SEN and FSM. SEN means Special Educational Needs students and FSM means Free School Meal students. The "Other policy changes" variable controls for whether there was a leadership or policy changes occurring at the time of the introduction of a mobile phone ban. $* * * \mathrm{p}<0.01, * * \mathrm{p}<0.05, * \mathrm{p}<0.1$ Sources: National Pupil Database (NPD) and author-conducted mobile phone survey. 


\title{
Table A.4: Effect of Mobile Bans on Student Performance by Student Characteristics
}

\author{
Age 16 Alternate Test Scores
}

(1)

(2)

(3)

(4)

(5)

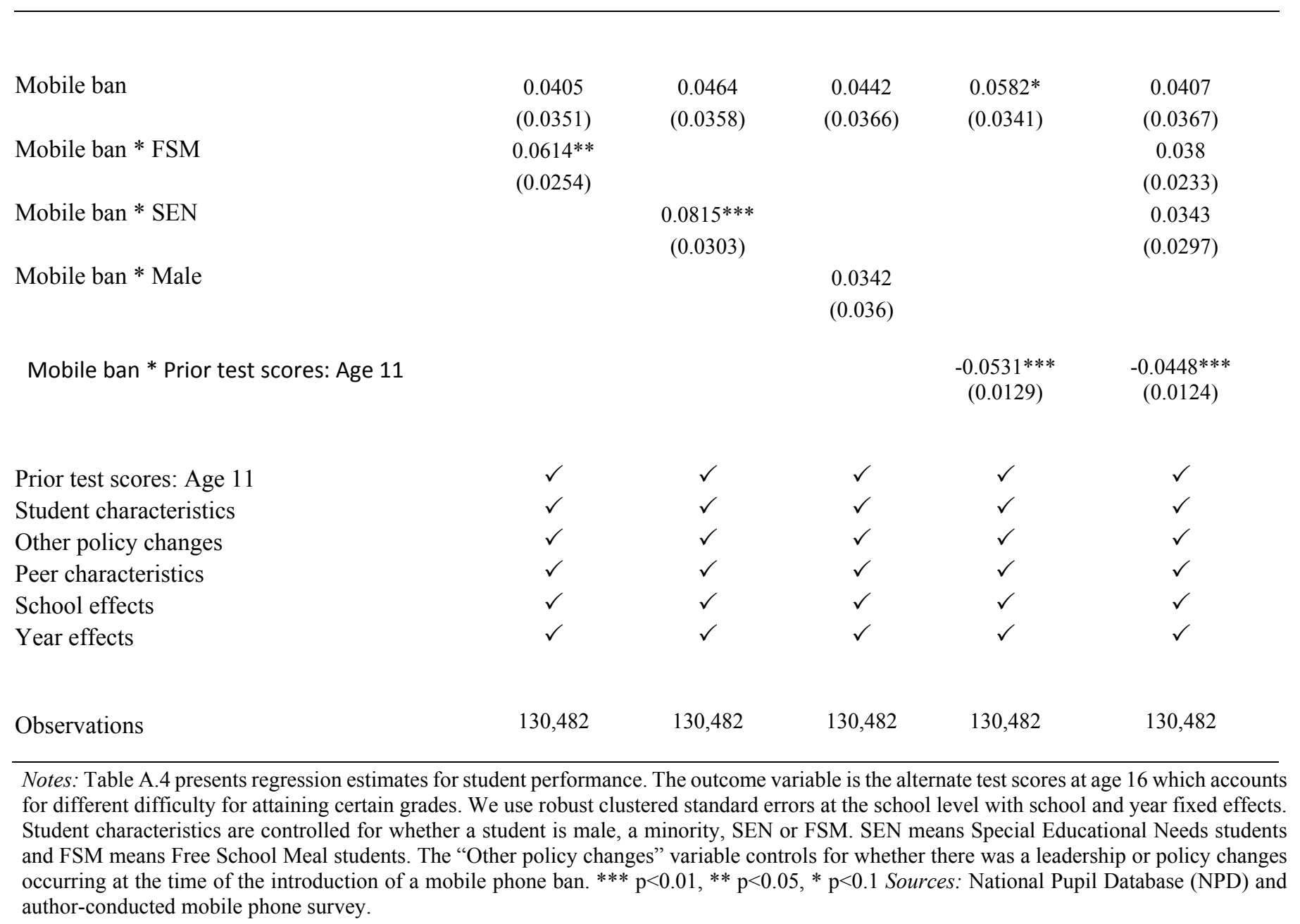


Table A.5: Effect of Mobile Bans on Student Performance by Prior Achievement Quintile: Age 11

\begin{tabular}{|c|c|c|c|c|}
\hline $\begin{array}{l}\text { Age } 16 \text { Alternative Test } \\
\text { Scores }\end{array}$ & (1) & (2) & (3) & (4) \\
\hline \multicolumn{5}{|l|}{ Impact by age 11 test scores } \\
\hline Mobile ban * 1st quintile & $\begin{array}{c}0.1080 * * * \\
(0.036)\end{array}$ & $\begin{array}{c}0.1189 * * * \\
(0.0371)\end{array}$ & $\begin{array}{c}0.1203 * * * \\
(0.0374)\end{array}$ & $\begin{array}{c}0.1183 * * * \\
(0.0375)\end{array}$ \\
\hline Mobile ban $* 2$ nd quintile & $\begin{array}{l}0.0910 * * \\
(0.0353)\end{array}$ & $\begin{array}{c}0.1018 * * * \\
(0.0358)\end{array}$ & $\begin{array}{c}0.1032 * * * \\
(0.0364)\end{array}$ & $\begin{array}{c}0.1013 * * * \\
(0.0366)\end{array}$ \\
\hline Mobile ban $* 3$ rd quintile & $\begin{array}{c}0.0593 \\
(0.0365)\end{array}$ & $\begin{array}{l}0.0680 * \\
(0.0370)\end{array}$ & $\begin{array}{l}0.0691 * \\
(0.0376)\end{array}$ & $\begin{array}{l}0.0669 * \\
(0.0381)\end{array}$ \\
\hline Mobile ban $* 4$ th quintile & $\begin{array}{c}0.0267 \\
(0.0370)\end{array}$ & $\begin{array}{c}0.0237 \\
(0.0368)\end{array}$ & $\begin{array}{c}0.0247 \\
(0.0372)\end{array}$ & $\begin{array}{c}0.0217 \\
(0.0377)\end{array}$ \\
\hline Mobile ban $* 5$ th quintile & $\begin{array}{l}-0.0111 \\
(0.0381)\end{array}$ & $\begin{array}{l}-0.0212 \\
(0.0393)\end{array}$ & $\begin{array}{l}-0.0207 \\
(0.0397)\end{array}$ & $\begin{array}{l}-0.0243 \\
(0.0399)\end{array}$ \\
\hline $\begin{array}{l}\text { Test scores: Age } 11 \\
\text { categorical }\end{array}$ & $\checkmark$ & $\checkmark$ & $\checkmark$ & $\checkmark$ \\
\hline Student characteristics & & $\checkmark$ & $\checkmark$ & $\checkmark$ \\
\hline Other policy changes & & & $\checkmark$ & $\checkmark$ \\
\hline Peer characteristics & & & & $\checkmark$ \\
\hline School effects & $\checkmark$ & $\checkmark$ & $\checkmark$ & $\checkmark$ \\
\hline Year effects & $\checkmark$ & $\checkmark$ & $\checkmark$ & $\checkmark$ \\
\hline Observations & 130,482 & 130,482 & 130,482 & 130,482 \\
\hline
\end{tabular}

Notes: Table A.5 presents regression estimates for student performance. The outcome variable is the alternate test scores at age 16 which accounts for different difficulty for attaining certain grades. We use robust clustered standard errors at the school level with school and year fixed effects. Student characteristics are controlled for whether a student is male, a minority, SEN or FSM. SEN means Special Educational Needs students and FSM means Free School Meal students. In this table, students are grouped in five categories based on their achievement level at age 11, where group 1 is the lowestachieving group and group 5 is the highest-achieving group. The "Other policy changes" variable controls for whether there was a leadership or policy changes occurring at the time of the introduction of a mobile phone ban. $* * * p<0.01, * * p<0.05$, $* \mathrm{p}<0.1$. Sources: National Pupil database (NPD) and author-conducted mobile phone survey. 
Table A.6: Effect of Mobile Bans on Student Performance - Top 8 subjects

\begin{tabular}{|c|c|c|c|c|c|}
\hline $\begin{array}{l}\text { Age } 16 \text { Test Scores - Top } \\
8 \text { subjects }\end{array}$ & (1) & (2) & (3) & (4) & $(5)$ \\
\hline Mobile ban & $\begin{array}{l}0.0396^{*} \\
(0.0231)\end{array}$ & $\begin{array}{l}0.0434^{*} \\
(0.0233)\end{array}$ & $\begin{array}{l}0.0469^{*} \\
(0.0238)\end{array}$ & $\begin{array}{l}0.0474^{*} \\
(0.0242)\end{array}$ & $\begin{array}{l}0.0455^{*} \\
(0.0243)\end{array}$ \\
\hline $\begin{array}{l}\text { Prior test scores: Age } \\
11\end{array}$ & & $\checkmark$ & $\checkmark$ & $\checkmark$ & $\checkmark$ \\
\hline Student characteristics & & & $\checkmark$ & $\checkmark$ & $\checkmark$ \\
\hline Other policy changes & & & & $\checkmark$ & $\checkmark$ \\
\hline Prior peer achievement & & & & & $\checkmark$ \\
\hline School effects & $\checkmark$ & $\checkmark$ & $\checkmark$ & $\checkmark$ & $\checkmark$ \\
\hline Year effects & $\checkmark$ & $\checkmark$ & $\checkmark$ & $\checkmark$ & $\checkmark$ \\
\hline Observations & 130,482 & 130,482 & 130,482 & 130,482 & 130,482 \\
\hline
\end{tabular}

Notes: Table A.6 presents regression estimates for student performance. The outcome variable is the standardized test score at age 16 on top 8 subjects. We use robust clustered standard errors at the school level with school and year fixed effects. Student characteristics are controlled for whether a student is male, a minority, SEN or FSM. SEN means special educational needs students and FSM means Free School Meal students. The "Other policy changes" variable controls for whether there was a leadership or policy changes occurring at the time of the introduction of a mobile phone ban. ${ }^{* * *} \mathrm{p}<0.01,{ }^{*} \mathrm{p}<0.05,{ }^{*} \mathrm{p}<0.1$. Sources: National Pupil Database (NPD) and author-conducted mobile phone survey. 
Table A.7: Effect of Mobile Bans on Probability of Achieving 5 GCSEs Including English and Math

\begin{tabular}{|c|c|c|c|c|c|}
\hline $\begin{array}{l}\text { Age } 16 \text { Alternate Test } \\
\text { Scores }\end{array}$ & (1) & (2) & (3) & (4) & (5) \\
\hline Mobile ban & $\begin{array}{l}0.0190 * \\
(0.0098)\end{array}$ & $\begin{array}{l}0.0214 * * \\
(0.0096)\end{array}$ & $\begin{array}{l}0.0221 * * \\
(0.0094)\end{array}$ & $\begin{array}{l}0.0208 * * \\
(0.0094)\end{array}$ & $\begin{array}{l}0.0201 * * \\
(0.0094)\end{array}$ \\
\hline Prior test scores: Age 11 & & $\checkmark$ & $\checkmark$ & $\checkmark$ & $\checkmark$ \\
\hline Student characteristics & & & $\checkmark$ & $\checkmark$ & $\checkmark$ \\
\hline Other policy changes & & & & $\checkmark$ & $\checkmark$ \\
\hline Peer characteristics & & & & & $\checkmark$ \\
\hline School effects & $\checkmark$ & $\checkmark$ & $\checkmark$ & $\checkmark$ & $\checkmark$ \\
\hline Year effects & $\checkmark$ & $\checkmark$ & $\checkmark$ & $\checkmark$ & $\checkmark$ \\
\hline Observations & 130,482 & 130,482 & 130,482 & 130,482 & 130,482 \\
\hline
\end{tabular}

Notes: Table A.7 presents regression estimates for student performance. The outcome variable is the passing GCSE - EM. We use robust clustered standard errors at the school level with school and year fixed effects. Student characteristics are controlled for whether a student is male, a minority, SEN or FSM. SEN means Special Educational Needs students and FSM means Free School Meal students. The "Other policy changes" variable controls for whether there was a leadership or policy changes occurring at the time of the introduction of a mobile phone ban. ${ }^{* * *} \mathrm{p}<0.01, * * \mathrm{p}<0.05,{ }^{*} \mathrm{p}<0.1$ Sources: National Pupil database (NPD) and author-conducted mobile phone survey. 


\section{Table A.8: Effect of Mobile Bans on School Performance}

School Performance: \% of Students

(1)

(2)

(3)

(4)

Achieving 5 Cs, including English \& math

Mobile ban

0.0188 *

$0.0208^{* *}$

$0.0204 * *$

$0.0207^{* *}$

(0.0106)

(0.0104)

(0.0096)

$(0.0098)$

Prior test scores: Age 11

Mean student characteristics

Other policy changes

School effects

Year effects

Schools

Observations

$\begin{array}{ll} & \\ & \\ & \\ \checkmark & \checkmark \\ & \checkmark\end{array}$

$\begin{array}{ll}\checkmark & \checkmark \\ \checkmark & \checkmark \\ \checkmark & \checkmark\end{array}$

$\begin{array}{ll}\checkmark & \checkmark \\ \checkmark & \checkmark \\ & \checkmark \\ \checkmark & \checkmark \\ \checkmark & \checkmark\end{array}$

Notes: Table A.8 presents regression estimates for proportion of student who pass five GCSEs including English and Maths examinations. We use robust clustered standard error at the school evel. Student characteristics are controlled for whether a student is male, a minority, SEN or FSM. SEN means Special Educational Needs students and FSM means Free School Meal students. The "Other policy changes" variable controls for whether there was a leadership or policy changes occurring at the time of the introduction of a mobile phone ban. ${ }^{* * *} \mathrm{p}<0.01,{ }^{* *} \mathrm{p}<0.05,{ }^{*} \mathrm{p}<0.1$ Sources: National Pupil database (NPD) and authorconducted mobile phone survey. 


\section{CENTRE FOR ECONOMIC PERFORMANCE \\ Recent Discussion Papers}

1349 Nicholas Oulton

1348 Gianluca Benigno Nathan Converse Luca Fornaro

1347 Nitika Bagaria Barbara Petrongolo John Van Reenen

1346 Mark Bryan Alex Bryson

1345 Christos Genakos Mario Pagliero Eleni Garbi

1344 David Marsden

1343 George Ward

1342 Nicholas Oulton Gavin Wallis

1341 Camille Terrier

1340 Olivier Marie Ulf Zölitz

1339 Terence C. Cheng Joan Costa-i-Font Nattavudh Powdthavee
Space-Time (In)Consistency in the National Accounts: Causes and Cures

Large Capital Inflows, Sectoral Allocation and Economic Performance

Can Helping the Sick Hurt the Able? Incentives, Information and Disruption in a Disability-Related Welfare Reform

Has Performance Pay Increased Wage Inequality in Britain?

When Pressure Sinks Performance: Evidence from Diving Competitions

The Future of the German Industrial Relations Model

Is Happiness a Predictor of Election Results?

Integrated Estimates of Capital Stocks and Services for the United Kingdom: 1950-2013

Giving a Little Help to Girls? Evidence on Grade Discrimination and its Effect on Students' Achievement

'High' Achievers? Cannabis Access and Academic Performance

Do You Have To Win It To Fix It? A Longitudinal Study of Lottery Winners and Their Health Care Demand 
Why are Higher Skilled Workers More Mobile Geographically? The Role of the Job Surplus

1337 Misato Sato

Asymmetric Industrial Energy Prices

Antoine Dechezleprêtre

and International Trade

1336 Christos Genakos

Evaluating the Impact of Sunday Trading

Svetoslav Danchev

Deregulation

1335 Georg Graetz

Guy Michaels

Robots at Work

1334 Claudia Steinwender

The Roles of Import Competition and Export Opportunities for Technical Change

1333 Javier Ortega Gregory Verdugo

The Impact of Immigration on the Local Labor Market Outcomes of Blue Collar Workers: Panel Data Evidence

1332 David Marsden

Teachers and Performance Pay in 2014: First Results of a Survey

1331 Andrea Tesei

Trust and Racial Income Inequality: Evidence from the U.S.

1330 Andy Feng Georg Graetz

Rise of the Machines: The Effects of LaborSaving Innovations on Jobs and Wages

1329 Alex Bryson

Share Capitalism and Worker Wellbeing

Andrew E. Clark

Richard B. Freeman

Colin P. Green

1328 Esther Hauk

Schooling, Nation Building and

Javier Ortega

Industrialization: A Gellnerian Approach

\section{The Centre for Economic Performance Publications Unit \\ Tel 02079557673 Fax 02074040612 \\ Email info@cep.lse.ac.uk Web site http://cep.lse.ac.uk}

